\title{
Fighting for a regime change through active listening
}

\author{
Nelson Ribeiro ${ }^{1}$
}

Catholic University of Portugal, Portugal

\section{doi:10.5937/comman1430025R}

Summary: This article presents a case of political participation through radio broadcasting during World War II. Focusing on how the Portuguese listeners interacted with the transborder broadcasts from the BBC, it demonstrates how politically engaged citizens struggled to use a foreign station to disseminate their views on the country's political situation. Grounded on Pateman's (1970) and Carpentier's (2011) definitions of different levels of participation, it demonstrates that listeners were not given the ability to achieve full or maximal participation due to limitations imposed by organizational and political structures. Departing from this case, the article also reflects on how audiences interact with "traditional media", questioning the widespread idea of radio listeners as passive agents and suggesting that an understanding of the political and social contexts in which media participation takes place is essential to ascertain the levels of empowerment given to the audiences.

Keywords: audiences, BBC Portuguese Service, listener interaction, media participation, Oliveira Salazar, political participation; World War II

\section{Introduction}

Over the last few years the usage of new media to promote political and social change has become a recurrent theme in media studies (Fraser, 2007; Howard, 2011; Negroponte, 1996; O'Connor, 2012; Sifry, 2011; Tapscott, 1998). For those who advocate that the digital technologies can be used to

\footnotetext{
1 nelson.ribeiro@ucp.pt
} 
spread democracy and fight against dictatorships, today's new media environment is described as allowing all to participate and present their ideas in the public arena. Citizens are said to be empowered with the possibility of communicating to a mass audience: something that until the 1990s was reserved for those who possessed specific professional skills that allowed them to have access to broadcasting or publishing.

With the internet, the separation between the sender and the receiver is said to have been broken, which has led to the production of a large amount of literature on how journalism and mass media will change and/or survive in this new media landscape (Curran, 2010; Franklin, 2012; Herbert and Thurman, 2007; Küng et al., 2008; McChesney, 2012). This has also propagated the idea that ordinary citizens are replacing journalism as the "fourth estate" since they now possess the technologies that enable them to be heard by the ruling elite. Furthermore, while the internet has made it possible for citizens to produce and disseminate content, bypassing the traditional gatekeepers that are part of the institutionalized forms in which journalism is produced, many have questioned the real impact of the content produced by citizens arguing that these are being given a false sense of empowerment instead of real power (Hindman, 2008; Morozov, 2011). Still, some have praised the new participatory platforms that have emerged in the internet, namely the social networking sites (Qualman, 2009), while others have called attention to the fact that these platforms' main goal is not to generate a more plural debate in the public arena but to profit from the content produced by free labour (Langlois, 2011).

Hand in hand with this discussion that has taken central stage in the academic debate, a simplistic way of looking into the role of the media in previous times has also become dominant. In fact, many of those who praise the active media consumers, or produsers in the definition of Axel Bruns (2008) - tend to present the relationship between the receivers and what is now called "traditional media" as being something linear. In fact, the interaction between audiences and the media is mostly described in a dichotomy fashion: while the audiences of new media are said to be active and to possess the possibility to fully participate in the construction of media content, the audiences of previous media forms are described as passive, as if their level of involvement with newspapers, radio and television has been always limited to a simple act of consumption. 
Following Stuart Hall's seminal work (1973), the receivers of mass media were recognized the ability to decode media messages, therefore assuming a more active role than the one described by Lasswell (1927) or in the model of Shannon and Weaver (1949). However, if we look not at reception but at the level of production, the role of the mass media audience is still today mostly described as passive despite Henry Jenkins' Textual Poaching published in 1992 in which he demonstrated media fans' active role in recreating media texts. In this seminal work Jenkins examines how fans create fiction and other forms of expression through the appropriation of television shows. His analyses sheds light on the relationship between audiences and producers demonstrating how the former feel frustrated and powerlessness as a consequence of not being able to influence or interfere in programming decisions (1992: 121-122). Even though this has been an influential book, as Miroljub Radojković and Ana Milojević (2011) have demonstrated, still today the "traditional media" audience tends to be portrayed as a mere receiving structure with very little opportunity for interaction and participation in the production process. This, we believe, is the result of the fact that attention "has become focused on the participatory potential of 'new' media, which allows us to ignore the participatory capacities of 'old' media, and to underestimate their cultural importance and their institutional embeddedness in a capitalist economy" (Carpentier, 2009: 410).

With this article, we aim to contribute to overcoming the lack of attention given to how audiences interact with "traditional media" and to add complexity to the relationship established between individuals and these previous media forms, demonstrating that those engaged in civic and political movements did take an active stance and struggled to use the media available at a certain period of time to promote social or political change. In other words one might say that with this article we intend to demonstrate that the active role of citizens in the media as a form of political participation is not something new created by the digital technologies but something that is grounded on the individuals' political engagement which, as argued by Peter Dahlgren (1999), is a precondition for participation. Furthermore, we will also argue that limitations imposed on media participation have to be understood in a broader context focusing on political and social factors and not merely on technological issues since, as the case described below will demonstrate, restrictions imposed by organizational 
and political structures can be more powerful in limiting audience participation than the lack of adequate technological appliances.

We will illustrate media participation in the pre-internet period with the case of radio broadcasting in Portugal during World War II, demonstrating how Portuguese listeners interacted with foreign broadcasts, particularly the BBC, during a period in which radio was still considered a new medium. Questioning the widespread idea of radio as a unidirectional medium in which listening is usually presented as a mere passive action, we will analyze how politically engaged citizens struggled to use the British broadcasts to Portugal during the war as a means of undermining the dictatorship led by Oliveira Salazar that had ruled the country since 1933. Known as the Estado Novo (New State) it was a single-party regime that exercised severe control over individual rights, namely freedom of speech. All newspaper content was subjected to censorship while the national radio stations' output was controlled through ownership forms, economic strangulation and also censorship of news bulletins and other major spoken content (Ribeiro, 2010). The data here presented was collected through archive research conducted in Portugal and the United Kingdom, namely at the BBC Written Archives in Caversham, the National Archives in Kew Gardens and the Historical Diplomatic Archive in Lisbon. The content of letters sent by Portuguese listeners was analyzed in order to determine their perception of the broadcasts along with their expectations as regards the effect that their feedback would have on the station's editorial line. Documents produced by the Ministry of Information, the Foreign Office and the Portuguese diplomacy were also examined in order to develop an understanding of how governmental officials reacted to the audience engagement with the BBC.

As we have discussed elsewhere, it was mostly due to censorship imposed by the Salazar regime on Portuguese media during World War II that listening to foreign broadcasters became a habit among several sectors of Portuguese society. International shortwave transmissions were then the only sources available to the majority of the population that presented updated information on the military and political developments of the war. Among the stations that broadcast in Portuguese, the BBC became the most reliable source due to the Anglophile environment that existed in the country and also the station's strategy of focusing on news, as opposed to the transmissions from the Nazi's Reichs Rundfunk Gesellschaft (RRG) that mostly aired blatant propaganda (Ribeiro, 2011). 
Even though the BBC Portuguese Service, that started to operate in June 1939, was used by the British government to promote its views on the war and to apply pressure to Salazar on several occasions, the strategy adopted by the Voice of London of promoting itself as "the voice of truth" clearly paid off, enabling the station to achieve high listenership. This was, of course, good news for the British that had a particular interest in Portugal during the initial phase of the war since the Lisbon government had signed, in March 1939, a Treaty of Friendship and Non-Aggression with Spain. This gave Portugal the role of "an intermediary between Spain and the western democracies" (Telo, 1998: 138) at a time during which Franco's declared neutrality was not considered by the British Government as a real guarantee that Spain would not enter the war. ${ }^{2}$

Due to the small number of receivers available in Portugal, people would gather in private houses and public places to listen to the news from London, creating groups that functioned as social networks. Those who listened to the news of the day would pass it on to the other members of the group and a discussion on the military and political developments of the war would take place. The British station was made aware of listening habits through regular reports that it received from listeners and also from staff of the British Embassy in Lisbon. In fact, the BBC always encouraged listeners to provide feedback, which made it one of the first stations operating in Portugal that encouraged what we will designate as active listening, i.e. listener interaction with the producers providing feedback on the broadcasts. As will be discussed below, listeners went a step further than just providing feedback and used their interaction with the station to demand changes in the editorial line and to become active voices in the orientation of the broadcasts.

\section{The BBC broadcasts to Portugal and the importance of listener's feedback}

Assessing the public's opinion on the broadcasts was considered very important by the Portuguese Service right from the start of its transmissions. The Service counted on the help of its panel listeners to achieve this. The members of the panel had heterogeneous social and cultural backgrounds, as they were supposed to reflect the diversity of Portuguese society, making it possible to deter-

\footnotetext{
2 "Conclusions of a meeting of the War Cabinet", 4 November 1939, CAB/65/2/4.
} 
mine the reaction of different demographics. ${ }^{3}$ Moreover, the $\mathrm{BBC}$ also received, on a weekly basis, dozens of unsolicited letters from listeners. The majority of those that wrote belonged to the lower-middle class and one-third came from the upper and upper-middle class. This can be considered a fair reflection of the social make-up of Portuguese society. ${ }^{4}$ Nevertheless, the Corporation was not satisfied with these results and in 1943 it started to give particular attention to the feedback it received from upper class listeners, aiming to increase the appreciation of the Portuguese Service among the elite.

By considering the need to conquer the upper class a priority, the Service adopted a policy that led to a decrease in the number of entertainment programmes presented by the main and most well-known announcer of the Service, Fernando Pessa. Known for his unique and humorous style of presentation, he had widespread appeal among the lower and middle class listeners but he was severely criticized by the upper class in the letters that reached Bush House in London, where the Portuguese Service was housed.

Pessa, who had been a well-known announcer at the Portuguese public station before the war, was very much responsible for the BBC's popularity. Besides reading the news, he presented several features, including those in which Hitler was ridiculed. His success among the majority of those who listened to the $\mathrm{BBC}$ was undeniable and he easily connected with listeners by using common everyday expressions that attracted attention and created an intimate relation with those who followed his broadcasts on a regular basis. Besides being hugely popular, he was considered a hero by many listeners who believed that he was in charge of the whole Service. However, despite the flattering feedback he received from the low and middle class listeners, the BBC became almost obsessed in 1943 with the need to appeal to the upper class. As a result, letters sent to London by the more educated listeners were given better credit and because these criticised Pessa the BBC decided to take action making him feel

\footnotetext{
3 During the war the BBC established a panel of a few hundred regular listeners who reported back on a regular basis (Ribeiro, 2011: 302-303). Even though it remains unclear how people were selected and recruited to integrate the panel, by analysing the content of some of the letters sent to the BBC, it seems clear that the panel was intended to represent the different social classes and also to include people from different regions throughout Portugal.

4 According to the BBC Lisbon Observer, by May 1943 the audience of the Portuguese Service was composed as follows: upper class: 10\%; upper-middle class: 30\%; small shop-keepers, workmen and country people: $60 \%$. (Cf. "BBC Survey of European Audiences - Portugal", 25 May 1943, in the BBC Written Archives). Other BBC reports mention that the percentage of upper and upper middle class listeners represented approximately one-third of the total listeners.
} 
unwelcomed which led the Portuguese announcer to tender in his resignation and leave the Service in November $1943 .{ }^{5}$

Fearing the reaction from the majority of the listeners, his departure from the $\mathrm{BBC}$ was presented as being merely a holiday period. Nevertheless, this announcement was followed by some speculation about Pessa's relations with the BBC, causing some reactions from regular listeners who wrote complaining about his absence at the microphone:

It was with great regret that we heard Fernando Pessa's farewell although the announcement made by the "Man with the Walking Stick" gave us the hope that we might not lose our announcer. At the same time, if it had only been a question of ordinary holidays there would have been no need for a farewell [...]. Pessa said: "Until another day..."; but when is that day?

During December and the first few months of 1944, the regular letter writers and panel listeners constantly enquired as to when Pessa would return. A letter that reached the BBC said that "everybody in Lisbon knows he has left the $\mathrm{BBC}$ and why", adding that "in consequence, the BBC has lost a large percentage of its listeners". ${ }^{7}$ According to local reports this seemed to be the truth and the complaints that reached Bush House became overwhelming, which forced the $\mathrm{BBC}$ to invite Pessa to return to London. The invitation was done through the British Embassy in Lisbon ${ }^{8}$ and, as a consequence, he was back at the BBC microphones on 6 March 1944 and would continue to broadcast until June 1947.

As this case demonstrates, listeners had a relevant role in the life of the BBC Portuguese Service. However, it was the Corporation that had the last word and it decided, in different periods of time, which demographics would be given more attention, i.e. which active listeners would be given more credit and would be able to influence the content and the style of presentation. In fact, this raises a question about how mass media treat their receivers differently depending on socio-economic variables. In this particular case, the BBC clearly allowed its upper class listeners to have an active role in the decisions that were

\footnotetext{
5 BBC internal documents sent by Mr. Willimore to Press Office (Lisbon Embassy), 5 October 1943, in the BBC Written Archives, R13/199/2.

6 "BBC Survey of European Audiences - Portugal", 30 December 1943, in the BBC Written Archives.

"BBC Survey of European Audiences - Portugal", 28 February 1944, in the BBC Written Archives.

8 Cf. Fernando Pessa's testimony in Costa, $1996: 31$.
} 
being made inside the station, while its middle and lower class listeners were allowed a lower level of participation. This means that the symbolic power of each segment of listeners did gave rise to different reactions inside the $\mathrm{BBC}$ that mostly empowered those who were perceived as being close to power.

In relation to middle class listeners, as we have mentioned above, not only did they demand the return of Fernando Pessa to the BBC but they also requested that time slots ought to be reserved for popular programming in the construction of the programming schedule. The station gave in to these demands to a certain extent. However, what was at stake here was neither the $\mathrm{BBC}$ 's loyalty to the British government nor its positioning towards the Portuguese dictatorship. Nevertheless, many active listeners that were engaged in political movements and fought for a regime change in Portugal also interacted with the BBC expressing their views on how the station should take an assertive stance in the condemnation of a regime that restricted individual rights and that had clear ideological connections with the Axis. How did listeners express their political views to the British station and what were the consequences of this interaction? Can the role of active listeners be considered as political participation through the media? These are two questions that we intend to answer in the next section through an analysis of letters sent to the BBC by listeners who expressed their political beliefs and also through an understanding of the effect this feedback had on the daily life of the Service.

\section{From media to political participation}

During World War II, and despite the existence of different phases in the relationship between the British Government (and therefore the BBC) and the Portuguese regime, the BBC's editorial line was mostly marked by a cautious attitude regarding Salazar and the Estado Novo, which raised different reactions among the Portuguese listeners. Those who were in agreement with the Lisbon political regime did not have any strong reasons to protest against the Portuguese Service since it never directly attacked either Salazar or his Government. Even during the first half of 1944, when the exports of the precious metal tungsten from Portugal to Germany were addressed on the broadcasts, the BBC did not criticise the Estado Novo itself but instead focused only on the exports, avoiding references to the nature and the political positioning of the Portuguese regime. 
This cautious attitude did not prevent some moments of tension between the British and the Portuguese authorities. This happened mainly because Salazar expected that the Portuguese Service would praise his own work and be, like him, totally against news items that praised the Russians or criticised authoritarian forms of government. Nevertheless, and despite the official protests that the Portuguese Embassy presented to the Foreign Office in London about the $\mathrm{BBC}$, until talks on tungsten exports and democracy were aired, which only occurred in 1944, there is no record of any complaint by listeners who defended the Estado Novo in relation to this official complaint about the BBC's "too liberal and pro-democracy editorial line" (Ribeiro, 2011: 375).

On the other hand, listeners not in favour of Salazar's regime were disappointed by the $\mathrm{BBC}$ broadcasts and this sentiment grew as war progressed to the Allies' advantage. Politically active citizens who could not openly express their political beliefs, due to the restrictions imposed on political association, actively wrote to the $\mathrm{BBC}$ commenting on the content of the broadcasts and criticizing what they considered to be an unjustified concern in pleasing Salazar and his regime.

In 1941, after the Portuguese Service introduced talks and entertainment features to its regular schedule, and therefore was not only airing news, those who listened and were politically active felt that they had the right to express to the $\mathrm{BBC}$ their desire for a shift in the station's editorial line. They intended for it to promote the need for a political change to occur in Portugal. This was considered even more crucial by those who were anti-regime, as most of the talks broadcast by the BBC during 1941 praised Salazar and his government:

We democrats most indignantly protest against a talk given by Oscar da Silva broadcast by the $\mathrm{BBC}$ on $5^{\text {th }}$ May, flattering those two rascals (Salazar and the Cardinal Patriarch) who robbed the Portuguese people of their liberty. Great Britain is losing many friends by such talks. ${ }^{\text {}}$

Commenting on these reactions, the person responsible for the Portuguese Service at the time, R.E. Broughton, wrote to the Ministry of Information giving notice that the excessive praising of Salazar might not be the best strategy to attract more listeners to the British cause, meaning that the feedback provided

\footnotetext{
9 Letter from a listener from Setúbal to the BBC, quoted in a letter from R. E. Broughton (BBC Portuguese Service) to C.W. McCann (Ministry of Information), 12 September 1941, in the National Archives, FO 371/26818.
} 
by listeners did have some impact on the way the BBC officials perceived the path to be followed by the broadcasts:

The question to be decided seems to be whether the broadcasting of talks in which the speakers identify themselves with the principles held by the Portuguese fascists and pro-German Catholics is going to bring them over to our side. Frankly I see no evidence to support this supposition, and I am convinced that nothing except the recognition that Great Britain will eventually win the war will make them change their sympathies. ${ }^{10}$

The internal documents of the Corporation show that the Estado Novo's elite did not write to the BBC. They mention an absence of reactions from wellknown Portuguese individuals close to Salazar and his power structure. This meant that those from the upper classes that wrote to the station were mainly those who expected a change in the internal situation and were active and attempting to directly influence the course of political affairs. Writing in May 1941, a listener from Vila Nova de Gaia, a village located in the North of the country, mentioned how disappointed he was that the BBC broadcasts took for granted that the Portuguese people were united around Salazar and his policy. He was one of many who complained about the Corporation's "compliance" with the Estado Novo:

I have decided to reply to some of the news the BBC has been giving out. Referring to a leading article in the "Times" you state that Salazar represents the united will of the Portuguese people. There could not be a more mistaken idea. This person does not represent even 10\%, because the Portuguese people are not in agreement with the crimes of which he had been the author. Besides, the Portuguese people are deeply attached to liberty and freedom of thought, which do not exist here. The "Times", the English people and especially the BBC, have lost $30 \%$ of their adherents through that article of 29.4.41... It is not worth while you're spending your time in praising Salazar. It will alienate some of your listeners altogether. ${ }^{11}$

\footnotetext{
${ }^{10}$ Letter from a Lisbon listener to the BBC, quoted in a letter from R. E. Broughton to C.W. McCann, 12 September 1941, in the National Archives, FO 371/26818.

${ }^{11}$ Letter from a listener from Vila Nova de Gaia to the BBC, quoted in a letter from R. E. Broughton to C.W. McCann, 12 September 1941, in the National Archives, FO $371 / 26818$ (underlining in accordance to the original).
} 
The talks dealing with issues concerning the internal situation in Portugal were the ones that motivated least enthusiasm. Many listeners pointed out Salazar was not to be moved by pro-Estado Novo broadcasts and called the BBC's attention to the fact that the Portuguese government was not truly hoping for an Allied victory but it was instead keeping good relations with both sides of the war. These kind of comments, such as the following from a listener in Estoril (near Lisbon), were intended to change the British perception about Salazar and to promote a more critical attitude towards his regime:

The Portuguese Government is sitting on the fence, hoping for the best, as did some other small neutral countries with the result that we all know... The reason is that the Portuguese Government is not really convinced which side is going to win and will continue to pander to whichever side may get the better of the other... ${ }^{12}$

Another line of feedback provided by listeners tried to convince the BBC officials that they were misinformed about the political situation existing in Portugal and that the majority of the population was "not favourable to the present government in Portugal". ${ }^{13}$ This kind of feedback clearly indicates that among those writing to the $\mathrm{BBC}$ were listeners belonging to the internal opposition. However, as this was very weak and not well organised at the time, the Press Attaché of the British Embassy in Lisbon, Marcus Cheke, was very cautious when analysing these comments. In a letter addressed to the Portuguese Section of the Ministry of Information, Cheke considered many of the letters to have emanated from "subversive political elements in Portugal who, primarily for motives of self-interest, wish to label Salazar and his Government as pro-German". ${ }^{14} \mathrm{He}$ also mentioned that the flattering of the Portuguese Head of Government was not such a bad policy as some letters that reached Bush House had mentioned:

I am not in any way suggesting that adulatory essays on Dr. Salazar should be a regular item of the $\mathrm{BBC}$ programmes, but from time to time favourable references should certainly be made to the real achievements of the

\footnotetext{
${ }^{12}$ Letter from a listener from Estoril to the BBC, quoted in a letter from R. E. Broughton to C.W. McCann, 12 September 1941, in the National Archives, FO 371/26818.

${ }^{13}$ Letter from a listener from Vila Franca de Xira to the BBC, quoted in a letter from R. E. Broughton to C.W. McCann, 12 September 1941, in the National Archives, FO 371/26818.

${ }^{14}$ Memorandum from Marcus Cheke (Lisbon Embassy) to Michael Stewart (Portuguese Section of the Ministry of Information), October 1941, in the National Archives, FO 371/26819.
} 
present Portuguese government. These are of the highest value in offsetting German propaganda which incessantly endeavours to identify British victory with a return to the disgraceful disorder of the pre-Salazar days. [...] To sum up, the BBC should eschew Portuguese internal politics: it should give plenty of "straight news", and personal stories of British heroism: it should continue to ridicule and expose Hitler and the Nazis, [...] it should represent Britain as the seat of justice and fair play and of ordered freedom combined with justice." 15

By advocating that the broadcasts should continue on their path, not giving in to the negative feedback being received from some listeners, Marcus Cheke was of the opinion that the Portuguese Service should not "allow the relatively few anti-regime supporters to feel that they have the backing of the BBC." 16 Similar opinion was expressed by Colonel Pope who was responsible for the feedback on the BBC broadcasts until the nomination of the first Lisbon Representative which only took place in 1942:

The principle grumblers in letters to the B.B.C. are, I am almost certain, opposers of the present regime, who are trying to use the B.B.C. as a tool for attacking the present regime, hence their excessive criticisms of your praise of the present regime. It is necessary, therefore, to strike a very careful balance here. Anything about Germany, for instance, is most acceptable, and don't be too tame in your remarks. The general public like them, but the Germans here, of course, do not like the B.B.C. ${ }^{17}$

Although many of those who wrote to the $\mathrm{BBC}$ expected to receive the support of the British authorities in the condemnation of the Portuguese authoritarian regime, this support was not forthcoming. Furthermore, the Portuguese Service always maintained its distance from those that were expecting the BBC to play a more active role in terms of disseminating and promoting democratic values. This clearly reveals that active listening, in this case, understood to mean action taken by receivers that seek to participate in the construction of the content, did not ensure full participation since the final decision remained with the

\footnotetext{
${ }^{15}$ Memorandum from Marcus Cheke (Lisbon Embassy) to Michael Stewart (Portuguese Section of the Ministry of Information), October 1941, in the National Archives, FO 371/26819 (underlining in accordance with the original).

${ }_{16}$ Summary of report nos. $105 \& 106$ - from 21 September to 5 October 1941, in the National Archives, FO 371/26819.
}

${ }^{17}$ Letter from Colonel Pope to R. E. Broughton, 4 October 1941, in the BBC Written Archives, EI/1165/4. 
producers, who therefore retained most of the power in the relationship. The BBC, with setting up a panel to assess listener feedback and appealing for listeners to write to Bush House, was in fact close to applying what Sidney Verba (1961) has defined as "pseudo-participation", creating the feeling that listeners were empowered when this was not really the case.

Nevertheless, and despite the fact that we cannot consider those who interacted with the BBC to be empowered, they did become a source of concern for the Portuguese government, which was made aware of the feedback sent to London. ${ }^{18}$ In a letter addressed to Salazar, the Portuguese Ambassador in London, Armindo Monteiro, stated how he was working to spread the idea among the British government that the letters produced by BBC listeners did not represent the national will and were written by a minority opposed to the Estado Novo. According to Monteiro, political opposition was so weak and so non-representative that it had no real presence in Portugal and, for this reason, its only form of action was to write letters to the BBC. ${ }^{19}$

As the war developed, many letters addressed to the Voice of London openly started to express the desire for political change in Lisbon. For some of those who listened, including an English resident in Lisbon who wrote in July 1943 , it was clear that the Corporation had to make a choice between pleasing the regime in power and openly defending democratic values. Those who wrote to the station were well aware that the BBC had a difficult task: "If you speak of the advantage of democratic institutions and of Russia's achievements, you upset the Government and the Nationalists and if you don't, you disappoint the others." 20

It is clear that those opposing the Estado Novo did try to use the BBC as a vehicle for disseminating their arguments against the regime in power. Some believed that Britain, as a democracy, would not allow the Estado Novo to continue to exist once the war had ended and the other authoritarian regimes had been dismantled. Several letters tried to create the image that all those in Portugal who defended the British and the Allied forces were also all simultaneously against Salazar's government:

\footnotetext{
${ }^{18}$ Confidential letter from Armindo Monteiro to Salazar, 16 September 1941, in Rosas, Barros and Oliveira, 1996: 183-184.

${ }^{19}$ Confidential letter from Armindo Monteiro to Salazar, 16 September 1941, in Rosas, Barros and Oliveira, 1996 : 185.
}

20 "BBC Survey of European Audiences - Portugal", 25 March 1943, in the BBC Written Archives. 
Nearly $100 \%$ of the Anglophiles disapprove of your excessive friendliness towards a certain Government and certain rulers who, I affirm, are in complete disagreement with your thoughts and institutions. It is not my opinion, but that of many of my good compatriots, that the BBC ought to use less "soft soap". ${ }^{21}$

As the war evolved, those who hoped for the end of Salazar's regime started to become more confident about political change. The overthrow of Mussolini was very important in this particular regard. The news was first heard in Portugal through the BBC evening broadcast of 25 July $1943,{ }^{22}$ and it was greeted with joy by all those who did not support Salazar's government. Many of them gained new hope that a regime change would take place in Portugal and there was a significant rise in the number of letters sent to the $\mathrm{BBC}$ condemning the Estado Novo. The letters underlined the connections between the nature of the regimes headed by Mussolini and Salazar. Some expressed the idea that those opposing the Lisbon government were now more active than ever:

These people [those opposing the government] - mostly of the artisan class - have been openly saying not only should the Portuguese Government have allowed free comment on Mussolini's departure, but that the time was ripe for clearing up all scandals connected with profiteering, hoarding and the export of foodstuffs across the border [...]. In fact, as I write, it looks very much as if a determined effort may be in active gestation, having as its aim a modification of Portugal's totalitarian regime. ${ }^{23}$

Despite its concern for not annoying the regime in power, after the opening of the Eastern Front, the BBC addressed the role of Russia in the war which caused some discomfort to Salazar. Nevertheless, even during the last phase of the war the broadcasts tended not to comment on Portugal's internal situation. Furthermore, the $\mathrm{BBC}$ omitted news about strikes and social protests while pieces of news about the Government's achievements could be regularly heard. This was not very well accepted by the more liberal listeners, who complained as a means of exercising pressure on the $\mathrm{BBC}$ so that it would introduce some alterations to its editorial line:

\footnotetext{
21 "BBC Survey of European Audiences - Portugal”, 16 July 1943, in the BBC Written Archives.

22 "BBC Survey of European Audiences - Portugal”, 30 October 1943, in the BBC Written Archives.

23 "BBC Survey of European Audiences - Portugal", 10 September 1943, in the BBC Written Archives.
} 
We are well aware [...] that flattery is, very often, the foundation of diplomacy, but, in this instance, it would be better to keep silent so that no contradictions are apparent in a future which is not far off. Here one lives in a permanent atmosphere of rumours, having their origin in the scarcity of news worthy of credence. ${ }^{24}$

As time went by and an Allied victory became foreseeable, some of the listeners confessed their disappointment with the fact that the BBC, despite airing some talks on democracy, did not openly defend the implementation of a democratic regime in Portugal:

[The Portuguese Service has never broadcast] even lightly, any criticism of the Fascist system and of the atrocities and persecutions practised by the Portuguese Government. [...] Nor [...] have we heard the slightest hope given to listeners that after the victory of the United Nations, the rights of the citizen, liberty of the press, and democracy for which the people of Portugal are wholeheartedly yearning, will be brought into being in Portugal. ${ }^{25}$

Churchill's speech on 24 May 1944 was a big disappointment to those who expected Britain to impose a change on Portugal. By guaranteeing no interference in neutral countries, the British Prime Minister frustrated many BBC listeners in Portugal who had up to that point believed that the Allied forces would force the end of Salazar's regime. Moreover, even after this speech, many regular listeners did not give up and continued to pressurize the $\mathrm{BBC}$ to alter its editorial line and to condemn the Lisbon government. Furthermore, the talks on democracy aired throughout 1944 (Ribeiro, 2013), together with several other features broadcast by the BBC after the liberation of Paris, were seen as a last hope that the British would impose democracy in the country. For those that expected external intervention, these talks were primarily seen as a first step by the British authorities to expose Portugal's authoritarian regime. Nevertheless, Salazar's survival instinct was stronger and led him to give in to the Allies' demands in time to be able to negotiate his continuation in power after the conflict had finished. All those who had believed that it would be impossible for his regime to continue after the defeat of the Fascist and Nazi regimes were disappointed.

\footnotetext{
24 "BBC Survey of European Audiences - Portugal", 30 October 1943, in the BBC Written Archives.

25 "BBC Survey of European Audiences - Portugal", 16 May 1944, in the BBC Written Archives.
} 


\section{Concluding Remarks}

The case of BBC broadcasts to Portugal during World War II clearly illustrates the unbalanced power relationship that existed between the producers (the $\mathrm{BBC}$ ) and the receivers. Even though the latter were given the possibility to interact with the station, and did so due to their commitment to actively participate in a political change, the fact is that their attempts to influence the editorial line of the Voice of London did not achieve the proposed goals. Therefore, and although the feedback provided by listeners did have some impact, influencing some decisions and leading to internal debates inside the BBC on its editorial line, the active listening that took place did not achieve a level of power that would enable us to consider it as full participation. Furthermore, the audience was not treated equally, meaning that those who were perceived as possessing more symbolic social power were given higher credibility and therefore achieved greater influence over the station's decisions.

Even though there is no fixed definition of media participation, and it is a "highly fluid and contested notion" (Carpentier, 2007: 87) that has been used to describe "a wide variety of different situations by different people" (Pateman, 1970: 1), it does seem consensual that empowerment of the receiver is required for it to exist. This means that the receiver ought to be given the possibility of directly influencing media content. This was not the case with the BBC Portuguese Service. Listeners were urged to provide feedback or, in order words, they were given the opportunity to interact, but that did not mean that they were invited to participate in the construction of the station's output. Instead of full participation, this configures a situation that Carole Pateman has defined as partial participation: "a process in which two or more parties influence each other in the making of decisions but the final power to decide rests with one party only" (Pateman, 1970: 70). In fact, the BBC provided access and encouraged its listeners to interact but retained the power of decision for itself.

If we take a more maximalist version of the concept of participation, like the one defended by Nico Carpentier (2011), this case could be considered not as true media participation but merely as media interaction, i.e. a minimal form of participation in which "media professionals retain strong control over process and outcome" (2011: 26). In any case, irrespective of how we stretch the use of the concept of participation, it still remains clear that the Portuguese listeners of the BBC during World War II cannot be described as passive receivers, 
or atomised members of a mass, as audiences of "traditional media" tend to be presented in order to legitimise the theoretical dichotomy that seems to have been created between the audiences of digital and previous media forms. This, on the other hand, has helped to establish the idea that political participation via the media is something new brought about by the digital environment and which, therefore, cannot find any kind of parallel in the past, a notion that this case contradicts.

We have argued that a simplistic vision of the role of the audience in broadcasting, reducing it to a passive attitude of consumption, has led us to neglect forms of participation and interaction developed by politically involved communities that, in different historical moments, have used "traditional media" to engage in the political debate. Looking back to the $20^{\text {th }}$ century, we will find evidence of how politically engaged individuals have managed to participate in the media, even in authoritarian contexts, namely through the creation of clandestine newspapers and broadcasters. These examples, along with the one described in this article and others where audiences have had an active role in struggling to influence the editorial line of media organizations, do constitute cases of political participation through the media. Such cases can, however, only be understood when taking into account the context in which they take place, namely the power struggles involving all those who seek to determine the content produced and disseminated by the media. The case analysed herein highlights that the nature of the participation in mass media is dependent on power logics and can only be fully ascertained after it takes place, when a contextual analysis of the entire communication process can be conducted.

Furthermore, it seems that to understand the origins of interactivity, we should not focus so much on the technology but rather on how social movements (engaged in political or social change) have used all the means at their disposal, in different periods of time, to give visibility to their ideas and proposed plans. This said, we agree with Rob Cover who, departing from Raymond Williams' (1981) cultural materialist perspective, considers that interactivity should "not be understood as the 'making available' of a newly-invented technological tool but the extension to media technologies of a culturally-constituted desire for communication that is located in the lived expressions of culture" (Cover, 2006: 143). 


\section{References}

Bruns, A. (2008) Blogs, Wikipedia, Second Life, and beyond: From production to produsage. New York: Peter Lang.

Carpentier, N. (2007). Participation and media. In Cammaerts, B. \& Carpentier, N. (eds.), Reclaiming the media: Communication rights and democratic media roles. Bristol: Intellect, pp. 87-91.

Carpentier, N. (2009). Participation is not enough: The conditions of possibility of mediated participatory practices. European Journal of Communication, 24(4), 407-420.

Carpentier, N. (2011). Media and participation: A site of ideological-democratic struggle. Bristol: Intellect.

Costa, L. F. da (1996). Peça por Pessa [A piece by Pessa]. Lisboa: TV Guia Editora.

Cover, R. (2006). Audience inter/active: Interactive media, narrative control and reconceiving audience history. New media \& society, 8(1), 139-158.

Curran, J. (2010). The future of journalism. Journalism studies, 11(4), 464-476.

Dahlgren, P. (1999). Media and political engagement. Cambridge: Cambridge University Press.

Franklin, B. (2012). The future of journalism. Developments and debates. Journalism studies, 13(5-6), 663-681.

Fraser, N. (2007). Transnationalizing the public sphere. On the legitimacy and efficacy of public opinion in a post-westphalian world. Theory, culture \& society, 24(4), 7-30.

Hall, S. (1973). Encoding and decoding in the television discourse. Birmingham: The University of Birmingham.

Herbert, J. \& Thurman, N. (2007). Paid content strategies for news websites: An empirical study of British newspapers' online business strategies. Journalism practice, 1(2), 208-226.

Hindman, M. (2008). The myth of digital democracy. New Jersey: Princeton University Press. 
Howard, P. (2011). The digital origins of dictatorship and democracy. New York: Oxford University Press.

Jenkins, H. (1992). Textual poachers: Television fans and participation culture. New York, London: Routledge.

Küng, L., Leandros, N., Picard, R. G., Schroeder, R. \& Wurff, R. van der (2008). The impact of the internet on media organisation strategies and structures. In Küng, L., Picard R. G. \& Towse, R. (eds.), The internet and mass media. London: Sage, pp. 125-148.

Langlois, G. (2011). Meaning, semiotechnologies and participatory media. Culture Machine 12. Accessed 21.08.2013. URL: http://www.culturemachine.net/index.php/cm/article/view/437/467.

Lasswell, H. (1927). Propaganda technique in the World War. London: Kegan Paul, Trench, Trubner \& Co.

McChesney, R. (2012). Farewell to journalism? Time for a rethinking. Journalism studies, 13(5-6), 682-694.

Morozov, E. (2011). The Net delusion: How not to liberate the world. London: Allen Lane.

Negroponte, N. (1996). Being digital. London: Coronet.

O'Connor, R. (2012). Friend, followers and the future. How social media are changing politics, threatening big brands, and killing traditional media. San Francisco: City Lights Books.

Pateman, C. (1970). Participation and democratic theory. Cambridge: Cambridge University Press.

Qualman, E. (2009). Socialnomics: How social media transform the way we live and do business. New Jersey: John Willey \& Sons.

Radojković, M. \& Milojević, A. (2011). A critical analysis of two audience prototypes and their participatory dimensions. CM: Casopis za upravljanje komuniciranjem: Communication Management Quarterly, 6(21), 181-202.

Ribeiro, N. (2010). The war of the airwaves in Portugal: Foreign propaganda on short and medium waves, 1933-1945. Journal of radio \& audio media, 17(2), 211-225.

Ribeiro, N. (2011). BBC broadcasts to Portugal during World War II: How radio was used as a weapon of qar. Lewiston: Edwin Mellen. 
Ribeiro, N. (2013). António Pedro: The voice of democracy in the BBC Portuguese Section during World War II. Portuguese cultural studies, 5. 70-90.

Rosas, F., Barros, J. L. de \& Oliveira, P. de (1996). Armindo Monteiro e Oliveira Salazar. Correspondência Politica 1926-1955 [Armindo Monteiro and Salazar: Political correspondence 1926-1955]. Lisboa: Editorial Estampa.

Shannon, C. \& Weaver, W. (1949). The mathematical theory of communication. Urbana: University of Illinois Press.

Sifry, M. L. (2011). Wikileaks and the age of transparency. New Haven \& London: Yale University Press.

Tapscott, D. (1998). Growing up digital: The rise of the Net Generation. New York: McGraw-Hill.

Telo, A. (1998). As Relaçôes Peninsulares num Período de Guerras Globais (1935-1945) [The Peninsular relations in a period of global wars (19351945)]. In Rosas, F. (ed.), Portugal e a Guerra Civil de Espanha. Lisboa: Colibri, pp. 133-151.

Verba, S. (1961). Small groups and political behaviour. Princeton: Princeton University Press.

Williams, Raymond (1981). Culture. Glasgow: Fontana. 